\title{
Napoleons mage
}

Napoleon Bonaparte fremstilles ofte i karakteristisk positur, med hånden plassert på magen. Kan denne gesten skyldes at keiseren hadde magebesvær?

Kunstneren Jacques-Louis David (17481825) var i flere år ansatt som hoffmaler hos Napoleon Bonaparte (1769-1821). I storstilte, nærmest pompøse tablåer forherliget David keiserregimets makt og prakt. Napoleon i studérkammeret fra 1812 er riktignok en forholdsvis beskjeden fremstilling, men maleriet er ikke desto mindre velkjent. Den vanlige oppfatningen om at Napoleon alltid holdt den ene hånden over øvre del av magen, tilskrives ofte dette bildet. Opprinnelsen til et slikt kroppslig uttrykk er uklar, og i egne fora på Internett debatteres temaet inngående. I det følgende diskuteres fenomenet i lys av noen medisinske forhold.

\section{Keiserens gåtefulle død}

Det har vært skrevet mye om Napoleons helsetilstand, ikke minst om mulige årsaker til hans død. De siste leveårene på Sankt Helena var uten tvil preget av resignasjon og lidelse, og det terminale sykeleiet var langvarig (1). Fra høsten 1820 meldte de første alvorlige symptomene seg, i form av kraftige brekninger og hikke. I perioder forekom feber, dysuri, magesmerter og blodig oppkast. 3. mai 1821 forordnet dr. Archibald Arnott (1772-1855) en stor dose kalomel $\left(\mathrm{Hg}_{2} \mathrm{Cl}_{2}\right)$ mot kvalme, men dette forverret tilstanden og utløste kraftig melena, rask puls og profus svette. Døden inntraff to dager etter.

Obduksjonen ble foretatt av ikke mindre enn åtte leger, under ledelse av dr. Francesco Antommarchi (1780-1838) (1). Dette reflekterer nok like mye patologiens gryende betydning for medisinen som Napoleons status i samtiden. Selv om histologiske undersøkelser aldri ble utført, er autopsifunnene forenlig med ventrikkelcancer - forholdsvis nylig er det foreslått stadium T3N1M0 (2). Det kliniske bildet umiddelbart før døden kan passe med blødning fra magesekken, men omstendighetene er fortsatt gjenstand for engasjert diskusjon. Ikke minst har den alternative teorien om arsenikkforgiftning vært forfektet (1).

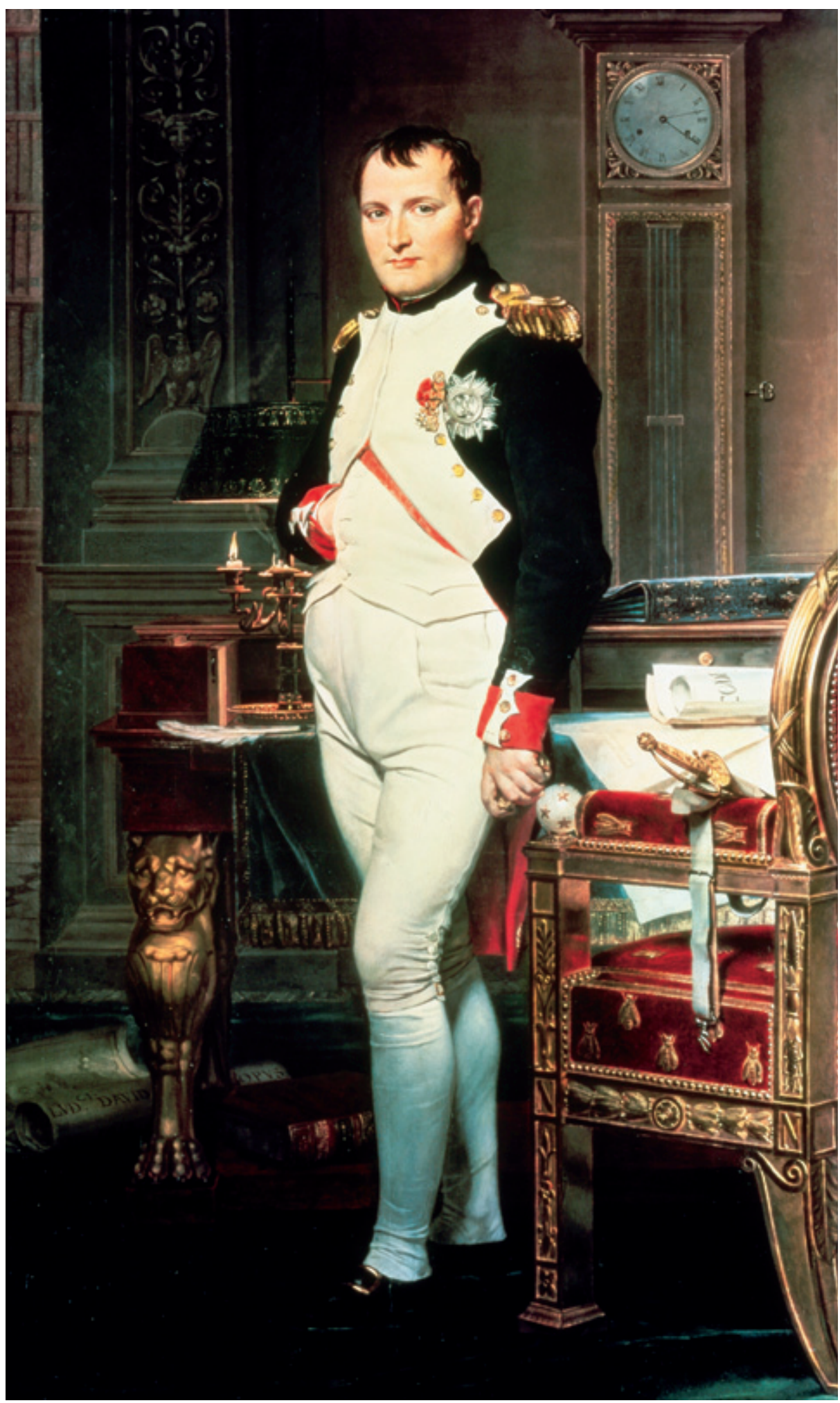

Napoleon i studérkammeret, malt av Jacqnes-Louis David i 1812. The National Gallery of Art, Washington D.C. Foto Interfoto, GV-Press/NordicPhotos 


\section{«Familiesykdommen»}

Hvis Napoleon hadde fătt lese sine egne autopsibeskrivelser, ville han neppe bli særlig overrasket. Han skal faktisk selv ha insistert på at magesekken skulle tas ut post mortem og studeres inngående, og at resultatet skulle meddeles sønnen i minste detalj (1). Carlo Buonaparte (1746-1785), keiserens far, døde 38 år gammel av ventrikkelcancer, og dette gjorde dypt inntrykk på den unge Napoleon. Han ble overbevist om at det hvilte en forbannelse over Bonaparteslekten, at kreft i magesekken var en «familiesykdom» som hjemsøkte dem (3).

Denne forestillingen var ikke tatt ut av luften, for flere av familiemedlemmene ble formodentlig rammet av samme lidelse (farfaren, en bror, tre søstre og fire søskenbarn) $(3,4)$. I ettertid har man lurt på om sykdomsopphopningen skyldtes en genetisk predisposisjon, men Helicobacter pyloriinfeksjon er kanskje vel så sannsynlig (4). Uansett er det rimelig å anta at Napoleons forventning om en dyster skjebne kan ha gjort ham ekstra var for signaler fra magen. Han søkte lege flere ganger for gastralgi, han bestilte kopier av farens obduksjonsrapport og han ba livlegen, dr. Jean-Nicolas Corvisart (1755-1821), om undervisning i ventrikkelens anatomi og fysiologi (3). Særlig fascinert ble han av termen «pylorus», hvor farens svulst var lokalisert. På dødsleiet skal en svekket og deliriøs Napoleon angivelig ha holdt seg til magen og gjentatt følgende setning: «O, mon pylore» (4).

«Une armée marche à son estomac» Napoleon var en eminent krigsstrateg, og innså tidlig betydningen av regelmessige måltider for soldatenes yteevne - derav ovenstående sitat som ofte blir tillagt Napoleon, og som direkte oversatt betyr «en hær marsjerer på sin mage». Godt organisert matforsyning til soldatene var et av keiserens viktigste anliggender, men i sitt private liv var Napoleon nok ikke like flink. Han var en travel mann, og sov og spiste svært uregelmessig (5). Han nøt ikke maten som en gourmet, men hadde heller hastverk med å få unna måltidene (4).

Det blir sagt at Napoleon alltid sultet før et slag og først spiste når seieren var sikret. Da var appetitten til gjengjeld stor, hvilket stilte krav til kokken. Vandrehistorier forteller at den berømte matretten kylling Marengo ble skapt på denne måten, ved at et begrenset utvalg lokale råvarer måtte raskes sammen $i$ all hast.

Napoleons etter hvert tiltakende overvekt kan nok tenkes å ha gitt ham gastroøsofageale refluksplager. I tillegg var keiseren angivelig melkeintolerant (4), og det er heller ikke utenkelig at stress utløste symptomer fra magen hans.

\section{Napoleons hånd}

Det er ingen plaget keiser som fremstilles i Davids maleri. Det er liten tvil om at Napoleon hadde stort besvær med magen i siste del av eksiltilværelsen på Sankt Helena, men det er åpent for spekulasjon om hva en eventuell dyspepsi kan ha betydd for hans avgjørelser i tiden før dette. Det står uansett fast at mannen klarte å bygge opp et omfattende imperium, med eller uten mageplager.

$\AA$ lese historiske hendelser med medisinske briller, med utgangspunkt i patografier, er fristende i Napoleons tilfelle. Og det er lov å lure på om det var en plagsom mage som fikk ham til å holde på den. Men vi må huske at det først og fremst var David som plasserte Napoleons hånd slik, og ikke nødvendigvis keiseren selv. I en grundig oversiktsartikkel (6) omtales plassering av hender innenfor vesten som et kulturhistorisk fenomen. Det viser seg at den franske keiseren ikke var alene om å bli gjengitt med en hånd over magen. Ikke minst innen britisk malerkunst var dette populært i Napoleons samtid. Ironisk nok ble både hertugen av Wellington (1769-1852) og lord Nelson (1758-1805) - Napoleons erkefiender - fremstilt på samme måte (riktignok bare ermet til lord Nelson: høyre arm ble amputert etter slaget ved Santa Cruz de Tenerife i 1797). Forbildene kan ha vært hentet fra antikken, der tilsvarende gester skulle tilføre skikkelsene en opphøyd verdighet. Belegg for dette kan vi blant annet finne hos Aeschines av Makedonia (390-331 f. Kr.), som i sin lærebok i retorikk påpekte at det var upassende å tale med hendene utenfor togaen (6).

Det sies at Napoleon selv var svært fornøyd med Davids bilde, uten at vi vet om han spesifikt kommenterte plasseringen av hånden. Opplevde han den som et typisk trekk hos seg selv, eller konstaterte han ganske enkelt at han ble fremstilt etter tidens normer? Napoleons mage og hånden under vesten vil nok fortsette å skape undring, på samme måte som Mona Lisas smil gjør det.

\section{Jørgen Valeur \\ jorgen.valeur@med.uib.no Institutt for indremedisin \\ Universitetet i Bergen}

\section{Oppgitte interessekonflikter: Ingen}

\section{Litteratur}

1. Hindmarsh JT, Corso PF. The death of Napoleon Bonaparte: a critical review of the cause. J Hist Med Allied Sci 1998; 53: 201-18.

2. Lugli A, Zlobec I, Singer G et al. Napoleon Bonaparte's gastric cancer: a clinicopathological approach to staging, pathogenesis, and etiology. Nat Clin Pract Gastroenterol Hepatol 2007; 4: $52-7$

3. Sokoloff B. Predisposition to cancer in the Bonaparte family. Am J Surg 1938; 40: 673-8.

4. Kubba AK, Young M. The Napoleonic cancer gene? J Med Biogr 1999; 7: 175-81.

5. Taylor B. A medical view of Napoleon I. Md State Med J 1976; 25: 35-45.

6. Meyer A. Re-dressing classical statuary: the eighteen-century «hand-in-waistcoat» portrait. Art Bull 1995: 77: 45-63.

Manuskriptet ble mottatt 13.6.2008 og godkjent 18.11.2008. Medisinsk redaktør Anne Gitte Hertzberg. 